\title{
Posture-reading by men's football goalkeepers and other factors in saving penalty kicks
}

\author{
Leitura pelo goleiro da postura do cobrador de pênaltis no futebol masculino e outros \\ fatores na defesa \\ Lectura por el golero de la postura del ejecutante de penales en el fútbol masculino y otros factores en la atajada \\ Manuel Sequeira ${ }^{a}$ (D) Sebastián Vallejo ${ }^{b}$ (D), Richard A. Fariñac* (D)
}

Keywords:

Soccer;

Training programme;

Goalkeeper;

Palavras-chave:

Futebol;

Cobrança de pênalti;

Goleiro;

Software para treino

Palabras clave:

Fútbol;

Software de

entrenamiento;

Golero;

Arquero;

Portero

\begin{abstract}
Penalty kicks are often decisive in football matches. Therefore, any technique that yields an advantage either in scoring or saving them is of great importance. Here we show the influence of a training programme for goalkeepers on the probability of defending penalties in men's football. Virtual training was used through an app that shows the shooter at the moment of setting the support foot on the ground and requiring the answer of which side (right or left) the ball will be directed at. Complemented with physical training, four sub 21 professional goalkeepers from Santarém, Brazil, developed the ability to correctly choose the side (left or right) at which the ball will be aimed. Sets of 800 penalties were kicked before (acting as control group) and after the training programme and it was found that, after training, the chances of saving penalty kicks or, at least, choosing the correct side, increase dramatically. It is concluded that the training programme improved the goalkeeper's ability to choose the correct side. Other factors (laterality and height) were not found to be statistically significant.
\end{abstract}

\section{RESUMO}

Os pênaltis são frequentemente decisivos em partidas de futebol. Portanto, qualquer técnica que produza uma vantagem tanto para marcar como para salvá-los é de grande importância. Aqui mostramos a influência de um programa de treinamento de goleiros na probabilidade de defesa de pênaltis no futebol masculino. O treinamento virtual foi utilizado por meio de um aplicativo que mostra o chutador no momento de colocar o pé de apoio no solo e exigir a resposta de qual lado (direito ou esquerdo) a bola será direcionada. Complementado com treinamento físico, quatro goleiros profissionais sub 21 de Santarém, Brasil, desenvolveram a habilidade de escolher corretamente o lado (esquerdo ou direito) para o qual a bola seria direcionada. Conjuntos de 800 pênaltis foram chutados antes (agindo como um grupo de controle) e depois do programa de treinamento e verificou-se que, após o treino, as chances de salvar pênaltis ou, pelo menos, de escolher o lado correto aumentam drasticamente. Conclui-se que o programa de treinamento melhorou a habilidade do goleiro em escolher o lado correto. Outros fatores (lateralidade e estatura) não mostraram ser estadísticamente significativos.

\section{RESUMEN}

Los tiros penales suelen ser decisivos en los partidos de fútbol. Por lo tanto, cualquier técnica que proporcione una ventaja, ya sea para anotar o para atajarlos, es de gran importancia. Aquí mostramos la influencia de un programa de entrenamiento para goleros sobre la probabilidad de atajar los penaltis en el fútbol masculino. Se utilizó entrenamiento virtual a través de una aplicación que muestra al tirador en el momento de poner el pie de apoyo en el suelo y que requiere la respuesta de hacia qué lado (derecho o izquierdo) se dirigirá el balón. Complementado con entrenamiento físico, cuatro goleros profesionales sub 21 de Santarém, Brasil, desarrollaron la capacidad de elegir correctamente el lado (izquierdo o derecho) al que se dirigiría el balón. Se lanzaron series de 800 penales antes (actuando

aCentro Universitário Luterano de Santarém, Curso de Educação Física. Santarém, PA, Brasil.

${ }^{\mathrm{b}}$ Grupo MAS, División Analytics. Montevideo, Uruguay.

'Universidad de la República, Departamento de Paleontología, Facultad de Ciencias. Montevideo, Uruguay.

*Corresponding author:

Richard A. Fariña

E-mail: dogor@netgate.com.uy

Received 18 june 2021; accepted 14 november 2021.

DOI: https://doi.org/10.1590/rbce.43.e007221 
como un grupo de control) y después del programa de entrenamiento y se encontró que, después del entrenamiento, las posibilidades de atajarlos o, al menos, elegir el lado correcto, aumentan drásticamente. Se concluye que el programa de entrenamiento mejoró la capacidad del golero para elegir el lado correcto. Otros factores (lateralidad y estatura) no mostraron ser estadísticamente significativos.

\section{INTRODUCTION}

Football association (soccer in some Englishspeaking countries) is undisputedly the most popular of sports.and has become a subject of scientific research in the last decades (Reilly et al., 1988, and Harvey, 2005). The game is peculiar in using feet instead of hands. Its collective nature renders skill less important than in other disciplines, often replaced by right decisions of the players and spatial intelligence (Leite and Guerra, 2004). However, biomechanics and science of movement in general (Kuhn, 1988; Belda Maruenda, 2009) are useful in a situation with controlled variables and more depending on technique: the penalty kick (Memmert et al., 2013). In this dramatic, face-to-face duel by only one player of each opposing team (shooter and goalkeeper), strict rules must be heeded (Arruda, 2013): the goalkeeper can move sideways but without leaving the goal line, the shooter must kick the ball in a forward direction towards the goal and cannot touch it again until another player does.

Since it is scored in $82 \%$ of the cases (FIFA, 2017), this is often a decisive event. Several factors affect its outcome, like the region of the goal the shot is aimed at (Fariña et al., 2013), the moment of the match (Almeida et al., 2016) and which major league is observed (Jamil et al., 2020). Moreover, many championships, including 4 out of 16 matches in the knockout stage of the last World Cup, decide draws through the shooting of penalty kicks following the FIFA rule.

Thus, decision making is paramount: behaviours of the two players involved as adopting an ecological dynamics perspective (Lopes et al. 2008). Also, the respective strategies are a typical example of escalation in evolutionary game theory (Shubik, 1971), in which the delay in making the decision allows the anticipation of the opponent's action (Wilson et al., 2018).

Furthermore, a cause-effect relationship is here proposed (Carvalhal et al., 2013): if biomechanics can help the goalkeeper in interpreting the shooter's posture and the diving can be performed in time and to the correct side (right or left) the ball is kicked at, the skill needed to optimise performance can be learnt (Carvalhal et al., 2013; Izzo et al., 2019) using a specifically created software (Morya et al., 2005; White et al., 2020).

The software is based on usual principles of visual perception training (McGuckian et al., 2018): if the goalkeeper, when the support foot of the shooter is on the ground, can acquire the capability of reading the inclination of the trunk (which coincides with the side the ball will be aimed at) and dive to that side within 0.5 seconds, the chances of saving are improved.
Other factors of potential importance will be assessed too. For instance, laterality is likely relevant in training (Stöckel \& Carey, 2016) since the goalkeeper's movement involves moving to the side as fast as possible: reaction times of right and left hands in individual sports are influenced by laterality (Badau et al., 2019). Diving to the side of the preferred limb is significantly faster than to the other side (Rebelo-Gonçalves et al., 2016).

Among other anthropometric and physiological variables (Ziv \& Lidor, 2011), the height of the goalkeeper (usually the tallest of football players; Leão et al., 2019), might also be important for enhancing performance at saving penalty kicks (Müller et al., 2018) - it seems likely that a taller person can reach more distant areas of the goal, as in the classic argument of Hill (1950).

Incidentally, well-reputed goalkeepers are thought to be taller by penalty kickers (Müller et al. 2018) but reputation was not considered here because our subjects were rather in the beginning of their careers (see Material and Methods). Also, the goalkeepers' position (i.e., slightly to one side from the centre of the goal) was not included as a variable, despite its demonstrated importance (Noël et al., 2015: Wood \& Wilson 2011). Hence, our results are valid when goalkeepers stand in the very centre of the goal in penalty kicks.

\section{MATERIAL AND METHODS}

The research was experimental, exploratory, descriptive and explanatory of a quantitative nature.

Three goalkeepers and two other players from the reserve team of the São Francisco Esporte Clube (SFEC, a professional club that participates in the under-20 championship of the Pará State) were observed in the field of the of the Associação de Funcionários do Instituto Brasileiro do Meio Ambiente (ASSIBAMA), Santarém, Brazil.

Following Bar-Eli and Azar (2009), the goal of official dimensions was divided in 15 regions (Figure 1 ) that were printed in a fabric adjusted to the goal using hooks. The players dressed in uniforms with visible marks on shoulders, elbows, wrists, hips, knees and ankles.

Using 4 official Penalty ${ }^{\mathrm{TM}}$ footballs, 960 penalties were kicked once a week from February to April 2014 in two 30-minute sessions per week of 40 shots after the usual training of the SFEC. Experiments, i.e., penalty kicks following the rules, were filmed with three previously calibrated and prepared cameras (Samsung digital camcorder SC MX10A NTC, digital camera Samsung HzW, Nikon Coolpix Full HD Movie). 
The movements of the players were decomposed with the software Kinovea. In frame-by-frame analyses of the players' movements, distance, time and angle of the shot as well as the direction of the ball were measured. The instant in which the kickers impacted the ball and the goalkeepers started their reaction movements were recorded.

The second phase of the experiment included two sessions per week of five 10-penalties series for each of the professional first division goalkeepers from São Raimundo and São Francisco teams in the Barbalhão and the Panterão stadiums in Santarém. As a complement of the observations on movements, those experienced goalkeepers were asked about the strategy used for saving penalties for enhancing the development of the training programme. Their opinions about the programme were also recorded.

In the third phase, goalkeepers were trained with the programme developed that included the use of computer simulations showing the view of a kicker about to shoot and the request of answering whether a dive to the left or to the right was needed (Tubino, 1984; Weineck, 2004; Orloff et al., 2008; Bompa and Buzzichelli,

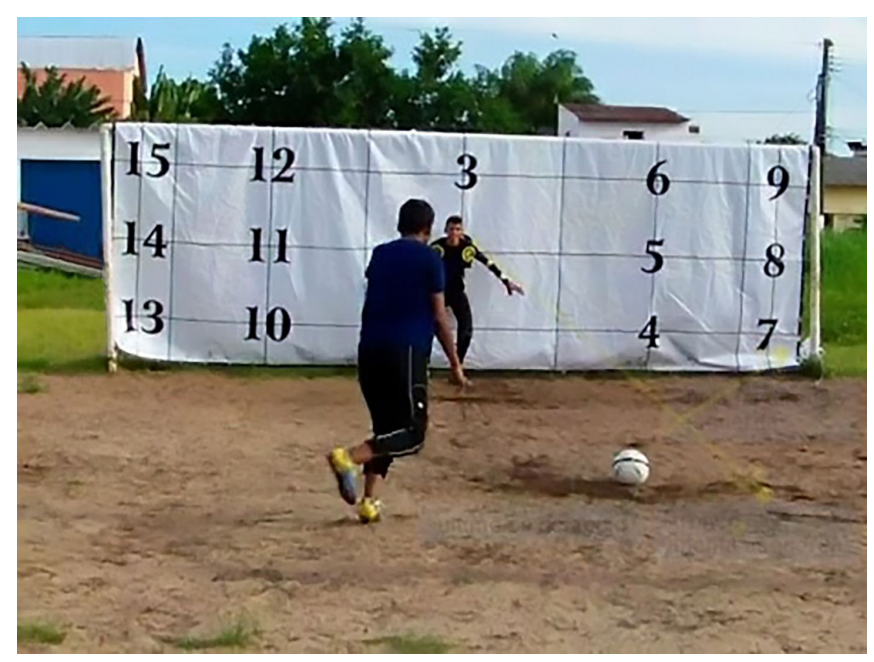

Figure 1. Beginning of the run towards the ball in apenalty kick. The goal area is divided as in Bar-Eli \& Azar (2009).
2015). Then, a new series of 800 penalties was kicked in the previously described order and arrangement.

\section{STATISTICAL ANALYSIS}

The data were analysed with the Student $t$-test. The null hypothesis $\left(H_{0}\right)$ implied that differences regarding the number of times goalkeepers chose the correct side before and after the training were explained by random variations not related to training. Similar analyses were performed to assess the contribution of the goalkeeper's laterality (ie, whether they were more successful while diving towards their preferred side or not) and height (ie, whether taller goalkeepers were more successful at saving penalties or not).

\section{RESULTS}

Tables 1 and 3 show data before and after training and Tables 2 and 4 , the coincidences between the side to which the ball was aimed at and the side to which the goalkeeper moved to (Figures 2-5).

The reaction time for the goalkeeper to correctly decide which side to dive at with chances to make the save (incidentally, in coincidence with the time at which the kicker's support foot touched the ground) was conguent with published values: $0.5 \mathrm{sec}$ (Bar-Eli and Azar, 2009).

In $28 \%$ of the cases, the goalkeepers chose the appropriate side before training and $63 \%$ after training, an increase of over two-fold (Figure 6), with differences in the coincidences being significant in both cases (left, $t=-6.57, \mathrm{p}=0.05$; right, $t=-10.39, \mathrm{p}=0.05$ ).

The height of the goalkeepers and the proportion of saves before and after the training was established to have tended to improve their performances to some extent although not significantly.

All goalkeepers in this study are right-handed and right-footed. They tended to dive more to their right side both before and after the training values. After the training, the coincidence of the correct diving towards their right increased.

Table 1. Penalties shot before training.

\begin{tabular}{lccccc}
\hline \multicolumn{1}{c}{ Goalkeeper } & Goalkeeper 1 & Goalkeeper 2 & Goalkeeper 3 & Goalkeeper 4 & Total \\
\hline Number & 200 & 200 & 200 & 200 & 800 \\
of penalties & 85 & 83 & 83 & 42 & 333 \\
Ball to the right & 44 & 34 & 71 & 77 & 171 \\
Ball to the centre & 71 & 83 & 85 & 92 & 296 \\
Ball to the left & 92 & 92 & 32 & 38 & 361 \\
Goalkkeper to the right & 22 & 16 & 83 & 70 & 108 \\
Goalkeeper to the centre & 86 & 92 & 23 & 41 & 331 \\
Goalkeeper to the left & 38 & 26 & 19 & 29 & 128 \\
Right/right coincidence & 24 & 27 & 99 \\
Lef/left coincidence & & &
\end{tabular}


Table 2. Coincidences between the side at which the ball was shot and the side to which the goalkeeper dived before training.

\begin{tabular}{ccc}
\hline Total coincidences & Right-Right & Left-Left \\
\hline 227 & 128 & 99 \\
\hline
\end{tabular}

Table 3. Penalties shot after training.

\begin{tabular}{lccccc}
\hline \multicolumn{1}{c}{ Goalkeeper } & Goalkeeper 1 & Goalkeeper 2 & Goalkeeper 3 & Goalkeeper 4 & Total \\
\hline Number & 200 & 200 & 200 & 200 & 800 \\
of penalties & 89 & 90 & 92 & 93 & 347 \\
Ball to the right & 35 & 30 & 40 & 39 & 174 \\
Ball to the centre & 76 & 80 & 68 & 68 & 279 \\
Ball to the left & 96 & 112 & 104 & 104 & 417 \\
Goalkkeper to the right & 14 & 07 & 15 & 12 & 54 \\
Goalkeeper to the centre & 90 & 81 & 81 & 84 & 329 \\
Goalkeeper to the left & 67 & 60 & 78 & 75 & 280 \\
Right/right coincidence & 60 & 50 & 52 & 65 & 227 \\
Lef/left coincidence & & & & & \\
\hline
\end{tabular}

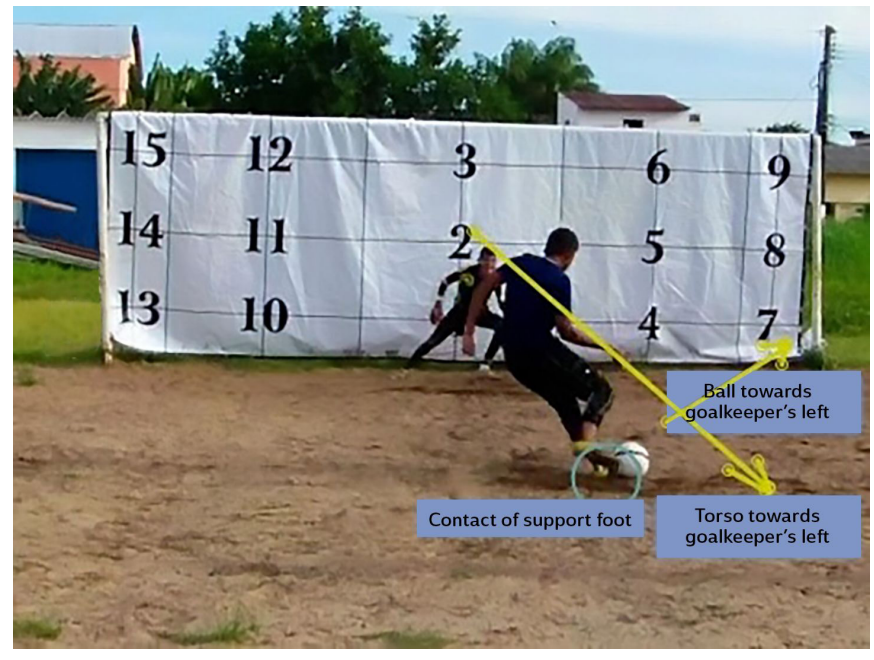

Figure 2. As the ball is impacted, the shooter's body leans to the left side of the goalkeeper.

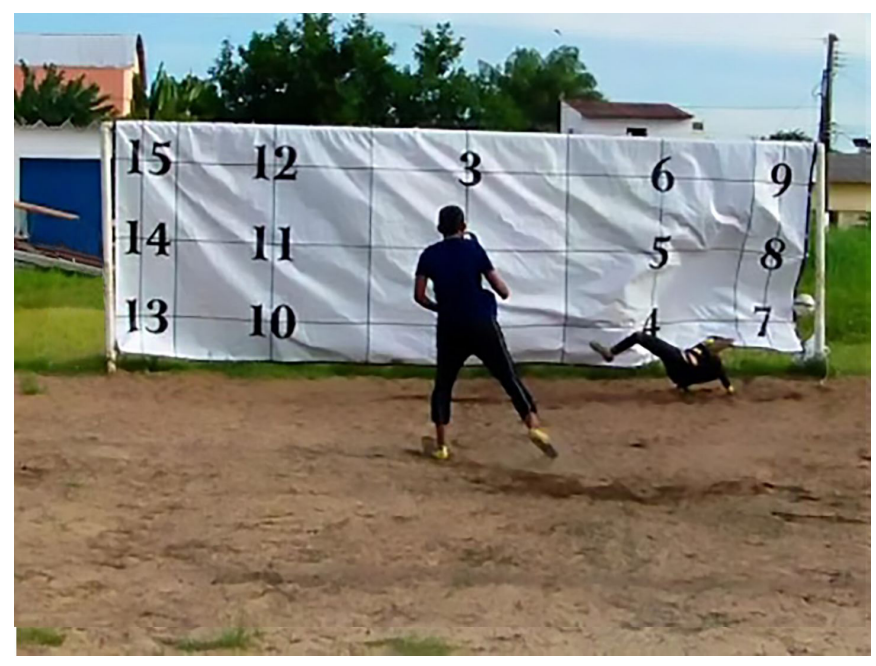

Figure 3. Same shot a fraction of a second later, with the goalkeeper diving towards his left side after correctly reading the shooter's posture.

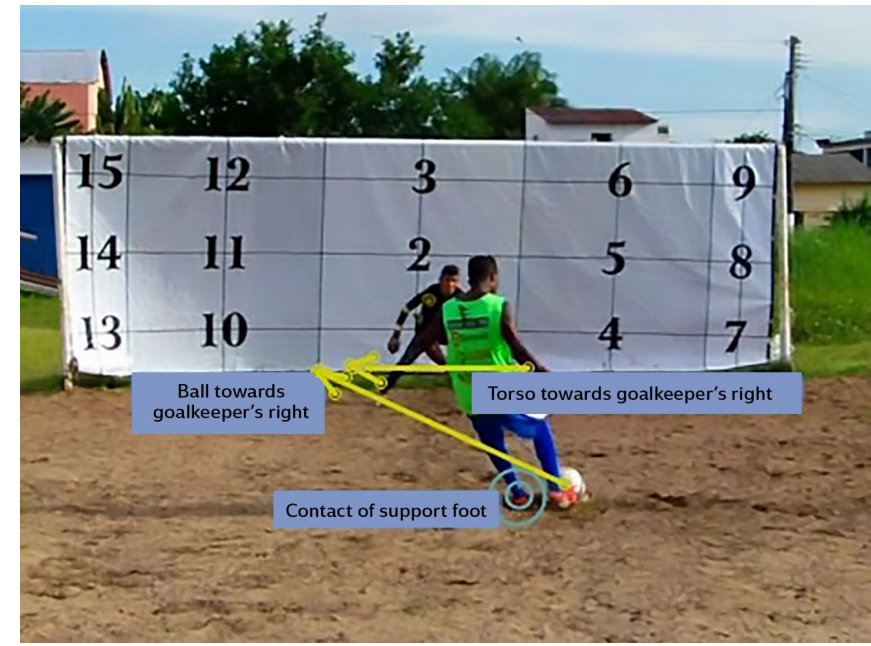

Figure 4. Moment of imoact on the ball be aimed at the right side of the goalkeeper. Shooter's body inclines towards his left (right, as seen by the goalkeeper).

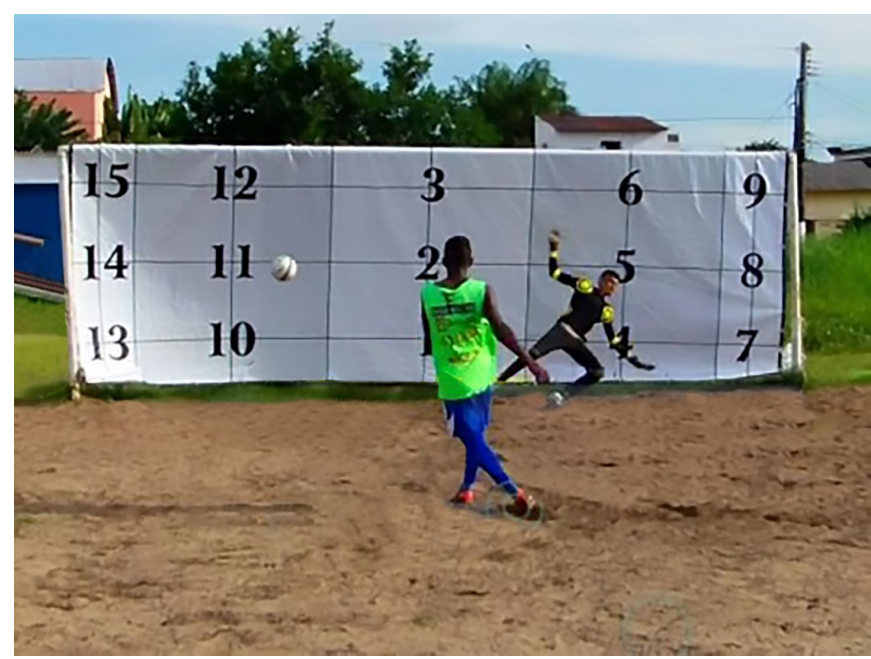

Figure 5. Wrong diving of the goalkeeper towards his left side. 
Table 5 provides the data of the contingency table computing showing the improvement after the training when the right decision is made before and after the programme, grouped by side kick/side chosen.

\section{DISCUSSION AND CONCLUSIONS}

\section{SIDE CHOICE}

The shots in penalty kicks are non-rotational (Nakamura et al., 2018), with the foot following a straight trajectory before hitting the ball. As predicted by

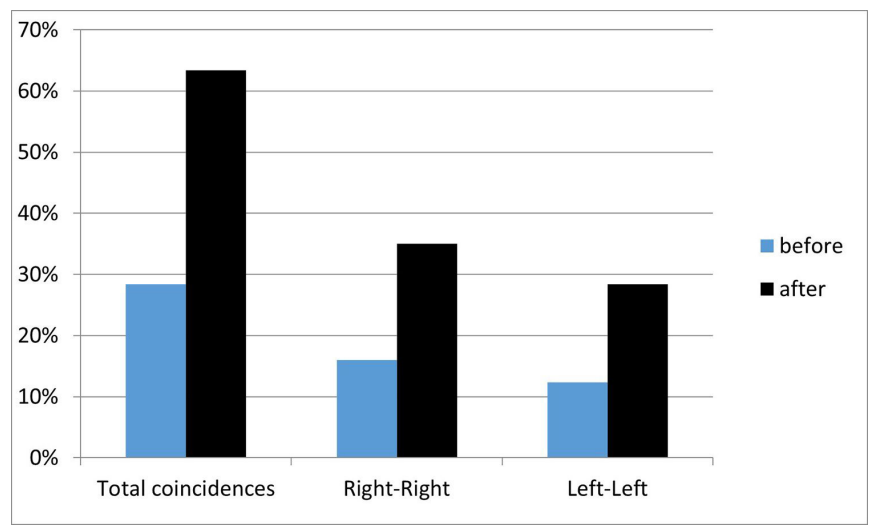

Figure 6. Coincidence comparisons of proportions of shots and dives before and after training.

Table 4. Coincidences between the side at which the ball is shot and the side to which the goalkeeper dives after training.

\begin{tabular}{ccc}
\hline Total coincidences & Right-Right & Left-Left \\
\hline 507 & 280 & 227 \\
\hline
\end{tabular}

conservation of the angular moment, it is biomechanically necessary, when the support foot touches the ground, to incline the trunk towards the same side the ball will be kicked at (Bar-Eli et al., 2007; Navarro et al., 2012; Nakamura et al., 2018; Biswas, 2018; Blair et al., 2018). Thus, for a left footed kicker that will direct the ball to the left of the goalkeeper, the (left) kicking foot should be closer to the support foot. In compensation, the trunk will balance on the right hip joint, swinging to the right (seen as to the left by the goalkeeper). If, however, a left-footed shooter aims at his left side, the ball must be impacted on a point that is closer to his body, usually by abducting the foot. The support foot must be placed farther away from the ball, which makes the trunk to be leaned to the left.

The shooter then reaches a non-return moment when the support foot lands and the kicking foot is swinging to hit the ball. The goalkeeper, after properly reading the posture of the shooter, has about 0.5 seconds to start the dive to the correct side (Kuhn, 1988), so increasing his chances of impeding the scoring (Lees et al., 2010).

It must be stressed that this game is basically endless (Campos, 2009) and this enhaced performance is meant to be ephemeral, as a counterstrategy will be eventually developed for shooters to beat the approach proposed here for goalkeepers.

\section{LATERALITY}

Known in old fossils far in the past of human evolution (Faurie et al., 2016), laterality is of general importance in sports practice in many ways (Loffing et al., 2016; Faurie et al. 2016), with fighting interactions (including sports as a way of physical confrontation, ritualised or not; Tirp et al., 2014; Harris 2016). Even other

Table 5. Results of computing the performance before/after the training grouped by side kick/side chosen when correct decision is made.

\begin{tabular}{|c|c|c|c|c|c|c|}
\hline & & \multicolumn{5}{|c|}{ Goalkeeper } \\
\hline \multicolumn{2}{|c|}{ Type of coincidence } & Goalkeeper 1 & Goalkeeper 2 & Goalkeeper 3 & Goalkeeper 4 & $\begin{array}{c}\text { Total shots by } \\
\text { side }\end{array}$ \\
\hline \multirow[t]{2}{*}{ BEFORE } & Right/Right & 38 & 26 & 23 & 41 & 333 \\
\hline & Left/Left & 24 & 27 & 19 & 29 & 296 \\
\hline AFTER & & Goalkeeper & & & & \\
\hline \multicolumn{2}{|c|}{ Type of coincidence } & Goalkeeper 1 & Goalkeeper 2 & Goalkeeper 3 & Goalkeeper 4 & $\begin{array}{c}\text { Total shots by } \\
\text { side }\end{array}$ \\
\hline & Right/Right & 67 & 60 & 78 & 75 & 364 \\
\hline & Left/Left & 60 & 50 & 52 & 65 & 292 \\
\hline \multicolumn{2}{|c|}{ Percentages of correct decisions } & \multicolumn{5}{|c|}{ Goalkeeper } \\
\hline & Coincidence & Goalkeeper 1 & Goalkeeper 2 & Goalkeeper 3 & Goalkeeper 4 & Mean \\
\hline \multirow[t]{2}{*}{ BEFORE } & Right/Right & $11,4 \%$ & $7,8 \%$ & $6,9 \%$ & $12,3 \%$ & $9,6 \%$ \\
\hline & Left/Left & $8,1 \%$ & $9,1 \%$ & $6,4 \%$ & $9,8 \%$ & $8,4 \%$ \\
\hline \multirow[t]{2}{*}{ AFTER } & Right/Right & $18,4 \%$ & $16,5 \%$ & $21,4 \%$ & $20,6 \%$ & $19,2 \%$ \\
\hline & Left/Left & $20,5 \%$ & $17,1 \%$ & $17,8 \%$ & $22,3 \%$ & $19,4 \%$ \\
\hline
\end{tabular}


mammals show lateral preferences for their movements and with differential performance (Murphy \& Arkins 2006) which is revealed early in life in humans (Gabbard \& Iteya, 1996).

The dominance of one limb over the other, even in regard to the essential task for a goalkeeper of positioning the arms (Imanaka et al., 1995; van der Kamp and Masters, 2008), becomes a concerning factor when the movement pattern of an athlete is adversely affected, especially from the point of view of biomechanics (Parrington \& Ball, 2016), including performance as well as injury prevention. Also, in the decision making of the kicker, our results suggest that correctly perceiving the laterality of the goalkeeper (Moore et al., 2017) is of importance in the success of scoring a penalty kick.

Studies on laterality in football have focused mainly on field players rather than on goalkeepers (Petro \& Szabo, 2016). Anyway, insight can be obtained for the case of the movement; the differential speed of the extremities in football players differ significantly $\left(27.68 \mathrm{~m} . \mathrm{s}^{-1}\right.$ for the execution of the kick with the preferred leg vs. 23.49 for the non-preferred leg; Vaverka et al. (2003), so rendering this disparity as a proxy of goalkeeper's performance when using his legs to dive to the side of their preferred leg or the other.

Players are found to be faster on the rotation of the contralateral side (Zouhal et al., 2018). Differences for movement times between right and left footed players in elite football players are significant $(p=0.039$, effect size $=0.413$, small) for both left and right rotation and only for the right rotation in amateur players.

Including specific training for laterality enhances performance in juvenile footballers (Pietsch and Jansen, 2018), According to Grouios (2004), sports have become a fertile area for laterality research, due either to the innate superiority of some motor dominance or the strategic advantage.

\section{STATURE}

Goalkeepers are the tallest among football players but no clear increased performance was observed for the tallest among them. Preliminary observations did not corroborate the previous idea that taller goalkeepers tend to perform better when the ball is directed to the areas more distant from the centre of the goal.

\section{FINAL REMARKS}

Further studies with more goalkeepers of varied statures as well of such other factors like the reaction times and the power in the jump. Also, binomial models are expected to shed new light on this process.

We claim that this training procedure is likely to be important also for female goalkeepers to some extent. However, the differences in the female pelvis are likely to influence the biomechanical requirement for female shooters to incline their trunks as described here for male players.

\section{FUNDING}

El presente trabajo no contó con apoyo fi nanciero de ninguna naturaliza para su realización.

\section{CONFLICTS OF INTEREST}

The authors report no conflict of interest.

\section{ACKNOWLEDGEMENTS}

This research was developed in the context of the Doctoral Programme ProlmBio, Facultad de Medicina, Universidad de la República, Montevideo, Uruguay. We acknowledge Samuel, Da Mota, Henrique and Sandrinho for their help in the observations. We are grateful to Julio Siciliano, Carlos Magallanes and Luciano Varela for their valuable comments. All players gave their informed consent to participate in the experiments.

\section{REFERENCES}

Almeida $\mathrm{CH}$, Volossovitch A, Duarte R. Penalty kick outcomes in UEFA club competitions (2010-2015): the roles of situational, individual and performance factors. Int J Perform Anal Sport. 2016;16(2):508-22. http://dx.doi.org /10.1080/24748668.2016.11868905.

Arruda M. Futebol: ciências aplicadas ao jogo e ao treinamento. São Paulo: Phorte; 2013.

Badau D, Baydil B, Badau A. Differences among three measures of reaction time based on hand laterality in individual sports. Sports. 2019;6(2):45. http://dx.doi.org/10.3390/ sports6020045. PMid:29910349.

Bar-Eli M, Azar OH, Ritov I, Keidar-Levin Y, Schein G. Action bias among elite soccer goalkeepers: the case of penalty kicks. J Econ Psychol. 2007;28(5):606-21. http://dx.doi. org/10.1016/j.joep.2006.12.001.

Bar-Eli M, Azar OH. Penalty kicks in soccer, an empirical analysis of shooting strategies and goalkeepers' preferences. Soccer Soc. 2009;10(2):183-91. http://dx.doi. org/10.1080/14660970802601654.

Belda Maruenda F. An offside position in football cannot be detected in zero milliseconds. Nat Preced. 2009:1-6. http:// dx.doi.org/10.1038/npre.2009.3835.1.

Biswas R. Continuous fuzzy evaluation methods: a novel tool for the analysis and decision making in football (or soccer) matches. Springer briefs in computational intelligence. Stuttgart: Springer Verlag; 2018.

Blair S, Duthie G, Robertson S, Hopkins W, Ball K. Concurrent validation of an inertial measurement system to quantify kicking biomechanics in four football codes. J Biomech. 2018;73:24-32. http://dx.doi.org/10.1016/j. jbiomech.2018.03.031. PMid:29602475.

Bompa T, Buzzichelli C. Periodization training for sports. 3rd ed. Champaign, IL: Human Kinetics; 2015.

Campos R. Imagens e tecnologias visuais em pesquisa social. São Paulo: Cultura; 2009. 
Carvalhal C, Lage B, Oliveira M. Futebol: um saber sobre o saber fazer. São Paulo: Prime; 2013.

Fariña RA, Fábrica G, Tambusso PS, Alonso R. Taking the goalkeeper's side in association football penalty kicks. Int J Perform Anal Sport. 2013;13(1):96-109. http://dx.doi. org/10.1080/24748668.2013.11868634.

Faurie C, Raymond M, Uomini N. Origins, development, and persistence of laterality in humans. In: Loffing $F$, Hagemann $\mathrm{N}$, Strauss B, MacMahon C, editors. Laterality in sports: theories and applications. New York: Academic Press; 2016. http://dx.doi.org/10.1016/B978-0-12-8014264.00002-X.

FIFA: Fédération Internationale de Football Association. The penalty kick in laws of the game. Zurich: FIFA; 2017. pp. 30-31.

Gabbard C, Iteya M. Foot laterality in children, adolescents, and adults. Laterality. 1996;1(3):199-205. http://dx.doi. org/10.1080/713754236. PMid:15513037.

Grouios G. Motoric dominance and sporting excellence: training versus heredity. Percept Mot Skills. 2004;98(1):5366. http://dx.doi.org/10.2466/pms.98.1.53-66. PMid:15058866.

Harris J. In fencing, are left-handers trouble for right-handers: Fencing masters said in the past what scientists say today. In: Loffing F, Hagemann N, Strauss B, MacMahon C, editors. Laterality in Sports: Theories and Applications. New York, Academic Press, 2016. http://dx.doi.org/10.1016/B9780-12-801426-4.00003-1.

Harvey A. Football, the first hundred years. London: Routledge; 2005.

Hill AV. Dimensions of animals and their muscular dynamics. Sci Prog. 1950;38:209-30.

Imanaka K, Abernethy B, Yamauchi M, Funase K, Nishihira $Y$. Hemispace asymmetries and laterality effects in arm positioning panel. Brain Cogn. 1995;29(3):232-53. http:// dx.doi.org/10.1006/brcg.1995.1280. PMid:8838384.

Izzo R, Giovannelli M, Raiola G. Training load in elite goalkeepers with K-Track for monitoring performance. J Phys Educ Sport. 2019;19:1890-6.

Jamil M, Littman P, Beato $M$. Investigating Inter-league and inter-nation variations of key determinants for penalty success across european football. Int J Perform Anal Sport. 2020;20:406-19. http://dx.doi.org/10.1080/24748668.20 20.1794720.

Kuhn W. Penalty-kick strategies for shooters and goalkeepers. In: Reilly T, Lees A, Davis K, Murphy WJ, editors. Science and football. London: E \& FN Spon; 1988.

Leão C, Camões M, Clemente FM, Nikolaidis PT, Lima R, Bezerra $P$, et al. Anthropometric profile of soccer players as a determinant of position specificity and methodological issues of body composition estimation. Int J Environ Res Public Health. 2019;16(13):2086. http://dx.doi. org/10.3390/ijerph16132386. PMid:31284403.

Lees A, Asai T, Andersen TB, Nunome H, Sterzing T. The biomechanics of kicking in soccer: a review. J Sports Sci. 2010;28(8):805-17. http://dx.doi.org/10.1080/02640414 .2010.481305. PMid:20509089.

Leite T, Guerra I. Ciência do Futebol. São Paulo: Manole, 2004.
Loffing F, Hagemann N, Strauss B, MacMahon C, editors. titulo. In: Loffing F, Hagemann N, Strauss B, MacMahon C, editors. Laterality in sports: theories and applications. New York: Academic Press; 2016.

Lopes JE, Araújo D, Peres R, Davids K, Barreiros J. The dynamics of decision making in penalty kick situations in association football. Open Sports Sci J. 2008;1(1):24-30. http://dx.doi. org/10.2174/1875399X00801010024.

McGuckian TB, Cole M, Pepping G. A systematic review of the technology-based assessment of visual perception and exploration behaviour in association football. J Sports Sci. 2018;36(8):861-80. http://dx.doi.org/10.1080/02640414. 2017.1344780. PMid:28650793.

Memmert D, Hüttermann S, Hagemann N, Loffing $F$, Strauss B. Dueling in the penalty box: Evidence-based recommenda-tions on how shooters and goalkeepers can win penalty shootouts insoccer. Int Rev Sport Exerc Psychol. 2013;6(1):209-29. http://dx.doi.org/10.1080/17 50984X.2013.811533.

Moore BB, Adams RD, O'Dwyer NJ, Steel KA, Cobley S. Laterality frequency, team familiarity, and game experience affect kicking-foot identification in Australian football players. Int J Sports Sci Coaching. 2017;12(3):351-8. http://dx.doi. org/10.1177/1747954117710513.

Morya E, Bigatão H, Lees A, Ranvaud R. Evolving penalty kick strategies: World Cup and club matches 2000-2002. In: Reilly T, Cabri J, Araújo D, editors. Science and Football V. The Proceedings of the World Congress on Science and Football. London: Routledge; 2005. p. 237-42. https://doi. org/10.4324/9780203412992.

Müller F, Best JF, Cañal-Bruland R. Goalkeepers' reputations bias shot placement in soccer penalties. J Sport Exerc Psychol. 2018;40(3):128-134. http://dx.doi.org/10.1123/ jsep.2017-0358. PMid:30008241.

Murphy J, Arkins S. Laterality and visuo-spatial ability in the equine: functional measures of sport horse selection? BSAP Occasional Publication. 2006;35:159-70. http:// dx.doi.org/10.1017/S0263967X00042646.

Nakamura T, Miyoshi T, Sato S, Takagi M, Kamada Y, Kobayashi Y. Differences in soccer kicking type identified using principal component analysis. Sports Eng. 2018;21(3):149-59. http://dx.doi.org/10.1007/s12283-017-0259-5.

Navarro M, Miyamoto N, van der Kamp J, Morya E, Ranvaud $R$, Savelsbergh GJP. The effects of high pressure on the point of no return in simulated penalty kicks. J Sport Exerc Psychol. 2012;34(1):83-101. http://dx.doi.org/10.1123/ jsep.34.1.83. PMid:22356884.

Noël B, van der Kamp J, Memmert D. Implicit goalkeeper influences on goal side selection in representative penalty kicking tasks. PLoS One. 2015;10(8):e0135423. http://dx.doi.org/10.1371/journal.pone.0135423. PMid:26267378.

Orloff H, Sumida B, Chow J, Habibi L, Fujino A, Kramer B. Ground reaction forces and kinematics of plant leg position during instep kicking in male and female collegiate soccer players. Sports Biomech. 2008;7(2):238-47. http://dx.doi. org/10.1080/14763140701841704. PMid:18610775. 
Parrington L, Ball K. Biomechanical considerations of laterality in sport. In: Loffing F, Hagemann N, Strauss B, MacMahon C, editors. Laterality in sports: theories and applications. New York, Academic Press, 2016. http://dx.doi.org/10.1016/ B978-0-12-801426-4.00013-4.

Petro B, Szabo A. The impact of laterality on soccer performance. J Strength Cond Res. 2016;38(5):66-74. http://dx.doi. org/10.1519/SSC.0000000000000246.

Pietsch S, Jansen P. Laterality-specific training improves mental rotation performance in young soccer players. Front Psychol. 2018;9:220. http://dx.doi.org/10.3389/ fpsyg.2018.00220. PMid:29535665.

Rebelo-Gonçalves R, Figueiredo AJ, Coelho-e-Silva MJ, Tessitore A. Assessment of technical skills in young soccer goalkeepers: reliability and validity of two goalkeeperspecific tests. J Sports Sci Med. 2016;15(3):516-23. PMid:27803631.

Reilly T, Lees A, Davis K, Murphy WJ, editors. Science and Football. London: E \& FN Spon; 1988.

Shubik M. The dollar auction game: A paradox in noncooperative behavior and escalation. J Conflict Resolut. 1971;15(1):10911. http://dx.doi.org/10.1177/002200277101500111.

Stöckel T, Carey DP. Laterality effects on performance in team sports: Insights from soccer and basketball. In: Loffing $F$, Hagemann N, Strauss B, MacMahon C, editors. Laterality in sports: theories and applications. New York: Academic Press; 2016. http://dx.doi.org/10.1016/B978-0-12801426-4.00014-6.

Tirp J, Baker J, Weigelt M, Schorer J. Combat stance in judo - Laterality differences between and within competition levels. Int J Perform Anal Sport. 2014;14(1):217-24. http:// dx.doi.org/10.1080/24748668.2014.11868716.
Tubino MJG. Metodologia científica do treinamento desportivo. São Paulo: Ibrasa; 1984.

van der Kamp J, Masters RSW. The human Müller-Lyer illusion in goalkeeping. Perception. 2008;37(6):951-4. http://dx.doi. org/10.1068/p6010. PMid:18686713.

Vaverka F, Janura M, Elfmark M. The velocity of soccer kicking and the laterality of the lower extremities. Analysis. 2003;387:103-18.

Weineck J. Optimales Fußballtraining. Balingen: Spitta Verlag; 2004.

White A, Hills SP, Hobbs M, Cooke CB, Kilduff LP, Cook $C$, et al. The physical demands of professional soccer goalkeepers throughout a week-long competitive microcycle and transiently through out match-play. J Sports Sci. 2020;38(8):848-54. http://dx.doi.org/10.1080/02640 414.2020.1736244. PMid:32122261.

Wilson R, Dicks M, Milligan G, Poolton J, Alder D. An examination of action capabilities and movement time during a soccer anticipation task. Movement and Sport Science. 2018;102(102):61-70. http://dx.doi.org/10.1051/ $\mathrm{sm} / 2019001$.

Wood G, Wilson MR. Quiet-eye training for soccer penalty kicks. Cogn Process. 2011;12(3):257-66. http://dx.doi. org/10.1007/s10339-011-0393-0. PMid:21318734.

Ziv G, Lidor R. Physical characteristics, physiological attributes, and on-field performances of soccer goalkeepers. Int J Sports Physiol Perform. 2011;6(4):509-24. http://dx.doi. org/10.1123/ijspp.6.4.509. PMid:22248551.

Zouhal H, Abderrahman AB, Dupont G, Truptin P, Le Bris R, Le Postec $E$, et al. Laterality influences agility performance in elite soccer players. Front Physiol. 2018;9:807. http:// dx.doi.org/10.3389/fphys.2018.00807. PMid:30008676. 